\title{
Influence of hepatitis $C$ virus on serum glutathione-S-transferase
}

\author{
Mircea Niculae Penescu', Corina-Daniela Ene (Nicolae) $)^{1 *}$, Emanoil Ceauşu $^{2}$, llinca Nicolae $^{2}$ \\ From The 10th Edition of the Scientific Days of the National Institute for Infectious Diseases "Prof Dr Matei \\ Bals" \\ Bucharest, Romania. 15-17 October 2014
}

\section{Background}

Glutathione-S-transferases (GST, E.C.2.5.1.18) are a family of enzymes that catalyze the conjugation of some harmful electrophilic compounds with glutathione, and thus, they are transformed in nontoxic lipophilic substances. In this study we aimed to evaluate the effect of hepatitis $C$ virus on serum level of GSTpi in patients with active systemic lupus erythematous (SLE).

\section{Methods}

Serum level of GSTpi was quantified by immunoenzymatic method in 42 patients with active systemic lupus erythematous (based on SLEDAI score), without any treatment divided in two groups: Group A - 30 cases with active SLE (SLEDAI = $11.2 \pm 3.2$ ), with chronic C hepatitis; Group B - 12 cases with active SLE (SLEDAI = $12.1 \pm 4.5$ ) without hepatitis $C$. The results were compared to those obtained in the control group, which included 42 healthy subjects.

\section{Results}

We determined increased levels of GSTpi in patients with active SLE without C hepatitis, when compared with the control group ( $236 \pm 82$ versus $211 \pm 68, \mathrm{p}>0.05)$. In patients from group B, the level of GSTpi was statistically significant higher than in patients from group A (286 \pm 36 versus $236 \pm 82, \mathrm{p}<0.05)$, respectively in control group $(286 \pm 36$ versus $217 \pm 39, \mathrm{p}<0.05)$.

\section{Conclusion}

The increased levels of GSTpi in patients with SLE and chronic $\mathrm{C}$ hepatitis sustain the hypothesis that the release of this intracellular enzyme might be influenced by

\footnotetext{
* Correspondence: koranik85@yahoo.com

${ }^{1}$ Carol Davila Clinical Hospital of Nephrology, Bucharest, Romania
}

Full list of author information is available at the end of the article hepatitis $C$ virus infection. This information might be useful for a better understanding of hepatitis $C$ pathogenesis.

\section{Authors' details}

${ }^{1}$ Carol Davila Clinical Hospital of Nephrology, Bucharest, Romania. ${ }^{2}$ Clinical Hospital of Infectious and Tropical Diseases "Dr. Victor Babeş", Bucharest, Romania.

Published: 15 October 2014

\section{doi:10.1186/1471-2334-14-S7-P39}

Cite this article as: Penescu et al:: Influence of hepatitis $C$ virus on serum glutathione-S-transferase. BMC Infectious Diseases 2014 14(Suppl 7):P39.

\section{Submit your next manuscript to BioMed Central and take full advantage of: \\ - Convenient online submission \\ - Thorough peer review \\ - No space constraints or color figure charges \\ - Immediate publication on acceptance \\ - Inclusion in PubMed, CAS, Scopus and Google Scholar \\ - Research which is freely available for redistribution \\ Submit your manuscript at www.biomedcentral.com/submit}

C Biomed Central

(c) 2014 Penescu et al; licensee BioMed Central Ltd. This is an Open Access article distributed under the terms of the Creative Commons Attribution License (http://creativecommons.org/licenses/by/4.0), which permits unrestricted use, distribution, and reproduction in any medium, provided the original work is properly cited. The Creative Commons Public Domain Dedication waiver (http:// creativecommons.org/publicdomain/zero/1.0/) applies to the data made available in this article, unless otherwise stated. 